\title{
REVIZIJA STANDARDA ZA AKREDITACIJU VISOKOŠKOLSKIH USTANOVA
}

\author{
dr Dragan Turanjanin, \\ dr Marija Marčetić
}

Reforme visokog obrazovanja i promene koje se u poslednjih desetak godina implementiraju nametnule su i donele nekoliko novina koje su visokoškolski sistem postavile i predstavile na drugačiji način od onog koji je do tada bio poznat kod nas. Zahtevi koje je pred visokoškolstvo postavila Bolonjska deklaracija i naši napori da se usaglasimo sa njom, otvorili su niz novih pitanja koja do tada nisu bila poznata niti su kao takvi egzistirali u visokom obrazovanju. U ovom radu izlazimo u susret naporima za poboljšanje kvaliteta u našem visokoškolskom obrazovanju. Nakon detaljnog prikaza osnovnih standarda predložene su izmene koje bi unapredila sistem kvaliteta. Predlozi dopune se tiču pre svega odgovarajućih standarda za akreditaciju visokoškolskih ustanova.

Ključne reči: standardi $u$ visokom obrazovanju, bolonjska konvencija, akreditacija

\section{Uvod}

z opšteg pojma kvaliteta može se zaključiti da kvalitet postaje jedan od glavnih fak-

tora konkurentske prednosti kako u proizvodnom, tako i u uslužnom sektoru, pa samim tim i u obrazovanju. Kako bi se izborile za svoju poziciju na globalnom tržištu, visokoškolske institucije moraju raditi na kvalitetu svojih usluga i pokazati otvorenost ka svetu. Pitanje kvaliteta visokog obrazovanja je pitanje od opšteg značaja, budući da od njega koristi imaju ne samo studenti već i poslodavci, država i čitavo društvo. Kvalitetno visoko obrazovanje obezbeđuje sposoban budući kadar, istraživanja i inovacije, što doprinosi rastu zaposlenosti kao i ekonomskom rastu i razvoju (Vranješ i sar., 2014). Shvatajući značaj poboljšanja kvaliteta visokog obrazovanja za razvoj, vlade evropskih zemalja započele su bolonjski proces, izmene zakona o visokom obrazovanju, a neke od njih su uspostavile obaveznu akreditaciju visokoškolskih ustanova i njihovih studijskih programa. Bolonjski proces se sastoji od serije promena u obrazovnom sistemu koji treba da rezultira zajedničkim evropskim obrazovnim sistemom koji se sastoji od uzajamno uporedivih, kompatibilnih i koherentnih obrazovnih potsistema. Trebalo bi ga postići usaglašavanjem akademskih stepena i osiguranjem kvaliteta visokoškolskih ustanova (Carlos \& Calvo, 2014). Postoje i autori koji tvrde da bolonjski proces postavlja temelje za osiguranje kvaliteta (Huet et al, 2011), ali i oni drugi koji tvrde da je Bolonjska deklaracija više stvar forme nego suštine (Veiga \& Amaral, 2012) i da je jedini opipljivi rezultat „bolonjskog univerziteta" pad kvaliteta obrazovnog procesa (Cvijanović i sar., 2007). 
Zahtevi koje je pred visokoškolstvo postavila Bolonjska deklaracija i naši napori da se usaglasimo sa njom, otvorili su niz novih pitanja koja do tada nisu bila poznata niti su kao takva egzistirala u visokom obrazovanju (Turanjanin, 2018). U ovom radu izlazimo u susret naporima za poboljšanje kvaliteta u našem visokoškolskom obrazovanju. Uvođenje kvaliteta je kontinuiran proces i zahteva stalnu dopunu i revidiranje kao i usaglašavanje sa zahtevima društva i privrede. Polazeći od te premise, a kroz analizu standarda koji su aktivirani kroz „Bolonju“, koji već koji su već na snazi u postupku obezbeđenja kvaliteta, dolazimo se do novih predloga za izmenu ili dopunu postojećih standarda. Izmene i dopune su sistematično predstavljene uporedo sa već primenjenim standardima propisanim zakonom i pravilnicima o akreditaciji u visokom obrazovanju. Rad daje prostor za buduću diskusiju o predstavljenom predlogu implementacije standarda.

\section{Akreditacija i implementacija standarda}

Već više puta pominjani Bolonjski proces i reforma visokog obrazovanja u Evropi, pa i kod nas, doveo je do akreditacije koja predstavlja proces pregleda i kontrole kvaliteta koji dozvoljava visokoškolskim ustanovama ili studijskim programima da budu priznati i zvanično sertifikovani kao oni koji ispunjavaju odgovarajuće standarde. Ostvarivanje standarda postavljenih akreditacijom smatra se minimalnim zahtevima za kvalitetno postignuće (Živaljević i sar., 2015). U visokom obrazovanju se ta vrsta kontrole naziva akreditacijom, s tim što to baš i nije ispravan naziv, jer upućuje na nešto što ustanova treba da ispuni samo jednom. U našem pozitivnom pravu je to rešeno tako što postoje dve vrste - a to je početna akreditacija kod ustanova koje se prvi put osnivaju i ponovna akreditacija - kada protekne utvrđeni vremenski period od kada je ustanova dobila početnu, odnosno prva akreditacija. Obzirom da je delatnost visokog obrazovanja dugoročna delatnost, visokoobrazovne ustanove se suočavaju sa eksternom kontrolom kvaliteta svakih 5-7 godina, te to može biti veliki broj puta, sve dok ustanova postoji.

Breme koje opterećuje Bolonjski proces i proces akreditacije tokom čitave njegove implementacije je nasleđeni logaritam obrazovanja do pre 2005. godine koji postoje deo kulture i tradicije hijerarhije u visokom obrazovanju u Srbiji. Suštinska i praktična promena u sistemu visokog obrazovanja nije učinjena. Domašaj Bolonje u Srbiji se upravo najviše osetio u procesu akreditacije (organi koji je sprovode i standardi po kojima se sprovodi), kontrole kvaliteta (koja ranije praktično nije ni postojala), te su se i samim tim studije, studijski programi, nastavni predmeti i sl., prilagodili tim obaveznim promenama. Onaj deo koji predstavlja najznačajniji deo Bolonje, mobilnost, odnos univerzitet - fakulteti, primenio se onoliko koliko je to bilo nužno zarad ispunjavanja preuzetih međunarodnih obaveza, a da se i dalje nastavilo sa radom koji je odavno postao deo kulture i kulturne tradicije visokog obrazovanja u Srbiji. Pristup analizi standarda kroz ovaj rad probaće da izbegne zamku formalizma. Standardi nisu shvaćeni kao puka prepreka za dobijanje dozvole za rad već kao značajan kriterijum u postizanju kvaliteta.

Polazna hipoteza u ovom radu je da uspostavljeni standardi u visokoškolskim ustanovama nisu sveobuhvatni, precizni i da je potrebno kritičko sagledavanje. Ovakvo mišljenje je na niz teoretskih rasprava mnogih autora kao i nosioca rada (Turanjanin, 2003,2007,2008). Radi uspešnijeg i jednostavnijeg prezentovanja aktuelnog postupka kontrole i provere kvaliteta u 
nastavku teksta date je tabela standarda koji se odnosi na pripremu dokumentacije za akreditaciju koju popunjava visokoškolska ustanova zajedno sa predlozima izmene. Otklanjanje nedostataka kod ovog standarda imalo bi uticaja na ostale standarde.

\section{Predlog izmene i dopune standarda „Uputstvo za pripremu dokumentacije za akreditaciju visokoškolske ustanove“}

Standardima se vrednuje kvalitet svakog pojedinačnog procesa koji postoji na visokoškolskoj ustanovi i iz takvog vrednovanja se donosi zaključak o tome da li određena ustanova i određeni studijski program zadovoljavaju minimum uslova u pogledu kvaliteta, predviđen Zakonom o visokom obrazovanju i ostalim podzakonskim aktima koje su na osnovu zakona doneti i usvojeni. Sledećom tabelom je precizirano koje dokumente određena visokoškolska institucija treba da prezentuje u procesu akreditacije. Uporedo sa svakim standardom navedeni su predlozi izmene i dopune koji su nastali kroz iskustvo autora u akreditacionom procesu.

Tabela 1 - Uputstva za pripremu dokumentacije za akreditaciju visokoškolske ustanove ${ }^{1}$

Standard 1: Osnovni zadaci i ciljevi visokoškolske ustanove

Visokoškolska ustanova ima utvrđene osnovne zadatke i ciljeve koji su

u skladu sa ciljevima visokog obrazovanja, koji su utvrđeni zakonom.

Opis (do 300 reči):

Pokazatelji i prilozi za standard 1:

Prilog 1.1. Publikacija ustanove, ili sajt ustanove

\section{Predlog izmene i dopune standarda 1}

Treba precizirati ko kontroliše opravdanost nave- Odbor za visoko školstvo parlamenta i Ministar-

denih ciljeva i zadataka visokoškolske ustanove.

stvo prosvete

\section{Standard 2: Planiranje i kontrola}

Da bi ostvarila osnovne zadatke i ciljeve, visokoškolska ustanova vrši planiranje i kontrolu rezultata svih oblika svojih obrazovnih, naučnih, umetničkih, istraživačkih i stručnih aktivnosti u okviru svoje delatnosti.

\section{Opis (do 100 reči):}

Pokazatelji i prilozi za standard 2:

Prilog 2.1. Usvojeni plan rada ustanove

Prilog 2.2. Godišnji izveštaj ustanove ili srodan dokument

\footnotetext{
${ }^{1}$ Iz Uputstva o akreditaciji visokoškolske ustanove, donetog na osnovu Pravilnika o standardima i postupku za akreditaciju visokoškolskih ustanova i studijskih programa, dostupnog na

https://www.kapk.org/sr/\%d0\%b0\%d0\%ba\%d1\%80\%d0\%b5\%d0\%b4\%d0\%b8\%d1\%82\%d0\%b0\%d1\%86\%d0 \%b8\%d1\%98\%d0\%b0/ / https://drive.google.com/file/d/0Bwr8qEMuakSJSmUzZXYtbHYwa3c/view pristupljeno 25.09.2017. godine.
} 


\section{Predlog izmene i dopune standarda 2}

Treba precizirati kojoj nadležnoj instituciji se podnosi plan rada i godišnji izveštaj.

Odbor za visoko školstvo parlamenta i

Ministarstvo prosvete

\section{Standard 3: Organizacija i upravljanje}

Visokoškolske ustanova ima organizacionu strukturu i sistem upravljanja koji obezbeđuju postizanje zadataka i ciljeva visokoškolske ustanove.

\section{Opis organizacione strukture i organa upravljanja ustanove (do 300 reči):}

\section{Pokazatelji i prilozi za standard 3:}

Tabela 3.1. Lista organizacionih jedinica u sastavu ustanove

Prilog 3.1. Statut ustanove

Prilog 3.2. Spisak članova Saveta visokoškolske ustanove

\section{Predlog izmene i dopune standarda 3}

Prilog 3.3. Spisak članova menadžmenta ustanove (izbor, trajanje, mandata) - kome se spisak dostavlja.
Odbor za visoko školstvo parlamenta i

Ministarstvo prosvete

\section{Standard 4: Studije}

Sadržaj kvalifikacija i diploma pojedinih vrsta i nivoa studija odgovaraju karakteru i ciljevima studijskih programa. Studijski programi visokoškolske ustanove su u skladu sa osnovnim zadacima i ciljevima i služe njihovom ispunjenju. Visokoškolska ustanova sistematično i efektivno planira, sprovodi, nadgleda, vrednuje i unapređuje kvalitet studijskih programa.

Opis (dati sa najviše $\mathbf{5 0 0}$ reči u slučaju univerziteta ili akademije strukovnih studija):

Opis kvalifikacije koje označavaju završetak osnovnih strukovnih studija

Opis kvalifikacija koje označavaju završetak osnovnih akademskih studija

Opis kvalifikacije koje označavaju završetak diplomskih akademskih studija

Opis kvalifikacija koje označavaju završetak specijalističkih akademskih studija

Opis kvalifikacija koje označavaju završetak specijalističkih strukovnih studija

Opis kvalifikacija koje označavaju završetak doktorskih studija

(Svaki pojedinačni opis dati sa najviše 100 reči u slučaju visokoškolske institucije)

\section{Pokazatelji i prilozi za standard 4:}

Tabela 4.1. Zbirni pregled studijskih programa koji se realizuju na univerzitetu ili akademiji strukovnih studija

Tabela 4.2. Lista studijskih programa koji se realizuju u visokoškolskoj instituciji

Prilog 4.1. Raspored časova za tekuću školsku godinu, programa koji se realizuju u visokoškolskoj ustanovi

Prilog 4.2. Dodatak diplomi za studijske programe koji se realizuju u visokoškolskoj ustanovi 


\begin{tabular}{|l|l|}
\hline \multicolumn{2}{|l|}{ Predlog izmene i dopune standarda 4} \\
\hline Nedostaje: & Odbor za visoko školstvo parlamenta i \\
1. zahtev o zajedničkim predmetima sa istim & Ministarstvo prosvete \\
planom i programom sa srodnim visokoškolskim & \\
ustanovama, a koji se mogu preneti. & \\
2. propis koliko časova iz jednog predmeta može & \\
biti na dnevnom nivou. & \\
3. propis koliko časova ukupno iz svih predmeta & \\
može student imati na dnevnom nivou. & \\
4. raspored kolokvijuma po svakom predmetu za & \\
tekući semestar (školsku godinu) & \\
5. treba precizirati kom nadležnom telu se gore & \\
navedeni zahtevi i propisi dostavljaju. & \\
\hline
\end{tabular}

\section{Standard 5: Naučnoistraživački i umetničkoistraživački rad}

Visokoškolska ustanova koja ostvaruje akademske studije ima organizovan naučnoistraživački i umetnički rad.

\section{Opis naučnoistraživačkih i umetničkoistraživačkih aktivnosti (ne duže od 300 reči):}

\section{Pokazatelji i prilozi za standard 5:}

Tabela 5.1. Zbirni pregled naučnoistraživačkih projekata koji se trenutno realizuju na univerzitetu

Tabela 5.2. Lista naučnoistražvačkih projekata koji se trenutno realizuju u visokoškolskoj ustanovi

Tabela 5.3 Lista saradnika uključenih u naučnoistraživačke i umetničkoistraživačke projekte koji se trenutno realizuju u visokoškolskoj ustanovi

Tabela 5.4 Zbirni pregled naučnoistraživačkih rezultata u ustanovi u prethodnoj kalendarskoj godini

Prilog 5.1. Plan naučnoistraživačkog ili umetničkoistraživačkog rada

Prilog 5.2. Dokument o akreditaciji ustanove kao NIO

Prilog 5.3. Godišnji izveštaj ustanove ili srodan dokument

Prilog 5.4. Spisak najznačajnijih objavljenih rezultata ustanove za prethodnu kalendarsku godinu (sistematisan po oznakama resornog Ministarstva, ne više od 50 referenci)

\section{Predlog izmene i dopune standarda 5}

Potrebno je navesti kom nadležnom telu se planovi, programi i rezultati dostavljaju.

Odbor za visoko školstvo parlamenta i

Ministarstvo prosvete

\section{Standard 6: Nastavno osoblje}

Visokoškolska ustanova zapošljava nastavnike, istraživače i saradnike koji svojom naučnom, umetničkom i nastavnom delatnošću omogućavaju ispunjenje osnovnih zadataka i ciljeva ustanove. Nastavno osoblje kompetentno ostvaruje studijske programe i ispunjava ostale dodeljene zadatke.

Opis (do 300 reči, za visokoškolsku ustanovu, a do 1000 reči za univerzitet $i$ akademiju strukovnih studija):

Pokazatelji i prilozi za standard 6: 
Tabela. 6.1. Pregled broja nastavnika po zvanjima angažovanih na univerzitetu

Tabela. 6.2. Pregled broja saradnika po zvanjima angažovanih na univerzitetu

Tabela. 6.1 A. Pregled broja nastavnika po zvanjima angažovanih na akademiji strukovnih studija

Tabela. 6.2 A. Pregled broja saradnika po zvanjima angažovanih na akademiji strukovnih studija

Tabela 6.3. Lista nastavnika angažovanih sa punim radnim vremenom

Tabela 6.4. Lista nastavnika angažovanih sa nepunim radnim vremenom

Tabela 6.5. Lista saradnika angažovanih sa punim radnim vremenom

Tabela 6.6. Lista saradnika angažovanih sa nepunim radnim vremenom

Tabela 6.7. Zbirni pregled broja nastavnika po oblastima, i užim naučnim ili umetničkim oblastima

Tabela 6.8 Organizacija nastave

Prilog 6.1. Izvod iz elektronske baze podataka poreske uprave republike Srbije

Prilog 6.1.a Ugovora u radu nastavnog osoblja sa punim radnim vremenom

Prilog 6.2. Pravilnik o izboru nastavnika

Prilog 6.3. Ugovori o angažovanju nastavnika sa nepunim radnim vremenom

Prilog 6.4. Saglasnost visokoškolske ustanove na rad nastavnika na drugoj visokoškolskoj ustanovi

Prilog 6.5. Raspored časova

\begin{tabular}{|l|l|}
\hline \multicolumn{2}{|l|}{ Predlog izmene i dopune standarda 6} \\
\hline 1.Nedostaje najvažnije za svakog nastavnika - & Odbor za visoko školstvo parlamenta i \\
oblast kojom se bavi doktorat, predmeti koje & Ministarstvo prosvete \\
predaju, za svaki predmet radovi koji ga & \\
kvalifikuju u izbor. & \\
2.Takođe, može se zahtevati raspored časova & \\
za svaki semestar, ko izvodi nastavu, koliko & \\
časova dnevno. & \\
3.Koja institucija je relevantna za kontrolu & \\
ispunjenja standarda nije precizirano. & \\
\hline
\end{tabular}

\section{Standard 7: Nenastavno osoblje}

Visokoškolska ustanova ima nenastavno osoblje koje svojim stručnim i profesionalnim radom obezbeđuje uspešnu realizaciju studijskih programa, osnovnih zadataka i ciljeva visokoškolske ustanove.

\section{Opis (do 100 reči):}

\section{Pokazatelji i prilozi za standard 7:}

Tabela. 7.1. Zbirni pregled nenastavnog osoblja po zvanjima i radnim mestima u visokoškolskoj ustanovi

Tabela 7.1 A (Polje: Prirodno-matematičke nauke, Tehničko-tehnološke nauke) Lista stručnih saradnika koji učestvuju u realizaciji laboratorijskih eksperimentalnih vežbi sa studentima

Prilog 7.1. Izvod iz elektronske baze podataka poreske uprave republike Srbije

Prilog 7.1.a Ugovori o radu nenastavnog osoblja 


\section{Predlog izmene i dopune standarda 7}

Nedostaje kom nadležnom telu se dostavljaju izveštaji, kvalifikacije stručnih saradnika i koliko

časova dnevno pokrivaju.

Odbor za visoko školstvo parlamenta i

Ministarstvo prosvete

\section{Standard 8: Studenti}

Saglasno osnovnim zadacima visokoškolska ustanova utvrđuje uslove za upis studenata i na osnovu toga vrši izbor kandidata. Visokoškolska ustanova obezbeđuje potrebne uslove studentima za uspešno savladavanje studijskih programa.

Opis (do 500 reči):

Pokazatelji i prilozi za standard 8:

Tabela 8.1. Zbirni pregled broja studenata po poljima koji studiraju na univerzitetu ili akademiji strukovnih studija u tekućoj školskoj godini

Tabela 8.2. Zbirni pregled broja studenata po poljima koji studiraju na univerzitetu ili akademiji strukovnih studija

Tabela 8.3. Pregled broja studenata po studijskim programima po godinama koji studiraju u visokoškolskoj ustanovi

Tabela 8.4. Zbirni pregled broja studenata po poljima koji su stekli diplomu na univerzitetu ili akademiji strukovnih studija

Tabela 8.5. Pregled broja studenata koji su stekli diplomu u visokoškolskoj ustanovi u prethodne tri školske godine

Tabela 8.6 A. Statistički podaci o napredovanju studenata (studije prvog stepena sa 180 ESPB)

Tabela 8.6 B. Statistički podaci o napredovanju studenata (studije prvog stepena sa 240 ESPB)

Tabela 8.6 V. Statistički podaci o napredovanju studenata (studije prvog stepena sa 240 ESPB)

Tabela 8.6 G. Statistički podaci o napredovanju studenata (studije drugog stepena sa 120 ESPB)

Tabela 8.6 D. Statistički podaci o napredovanju studenata (studije drugog stepena sa 60 ESPB)

Prilog 8.1. Konkurs za upis studenata u tekuću školsku godinu

Prilog 8.2. Rešenje o imenovanju komisije za prijem studenata

Prilog 8.3. Rang lista studenata upisanih na ustanovu u prethodnoj školskoj godini

Prilog 8.4. Evidencija prolaznosti i položenih ispita po predmetima i godinama

Prilog 8.5. Podaci o studentskom parlamentu

\section{Predlog izmene i dopune standarda 8}

Nedostaje:

1. ulazni uslove za svaki nastavni predmet (može

i ulazni kolokvijum);

2. posećenost nastave od strane studenata;

3. izveštaj o položenim kolokvijumima i izveštaj o položenom ispitu na kraju semestra (završni kolokvijum);

4. izveštaj o korelaciji posećenosti nastave i

položenim predmetima.

Odbor za visoko školstvo parlamenta i

Ministarstvo prosvete 
Standard 9: Prostor i oprema

Visokoškolska ustanova obezbeđuje prostor i opremu neophodne za kvalitetno izvođenje svih oblika nastave. Standardi prostora i opreme određuju se po obrazovno-naučnim, odnosno obrazovno-umetničkim poljima.

Opis (do 200 reči):

Pokazatelji i prilozi za standard 9:

Tabela 9.1. Lista objekata sa površinom u samostalnoj visokoškolskoj ustanovi - univerzitetu ili akademiji strukovnih studija

Tabela 9.1 A (Polje: Prirodno-matematičke nauke) Specifikacija laboratorijskog prostora koji visokoškolska ustanova obezbeđuje za izvođenje eksperimentalne nastave

Tabela 9.2 Lista prostorija sa površinom u visokoškolskoj ustanovi

Tabela 9.3. Lista vrednije opreme koja se koristi u nastavnom procesu u visokoškolskoj ustanovi

Tabela 9.4. Lista kapitalne opreme koja se koristi u nastavnom procesu - (oprema vredna više od $100.000 €$ )

Prilog 9.1. Dokaz o vlasništvu, ugovori o korišćenju ili ugovori o zakupu

Prilog 9.2. Izvod iz knjige inventara

Predlog izmene i dopune standarda 9

Nije precizirano u čijoj nadležnosti je kontrola

izveštaja.

Odbor za visoko školstvo parlamenta i

Ministarstvo prosvete

\begin{abstract}
Standard 10: Biblioteka, udžbenici i informaciona podrška
Visokoškolska ustanova ima odgovarajuću biblioteku snabdevenu potrebnim udžbenicima za izvođenje nastave i informacione resurse i servise koje koristi u cilju ispunjenja osnovnih zadataka.

Opis (do 200 reči):

Pokazatelji i prilozi za standard 10:

Tabela 10.1 Lista biblioteka u samostalnoj visokoškolskoj ustanovi - univerzitetu ili akademiji strukovnih studija

Tabela 10.2 Zbirni pregled broja bibliotečkih jedinica u visokošolskoj ustanovi

Tabela 10.3. Zbirni pregled broja udžbenika po oblastima (na srpskom i drugim jezicima) koji su dostupni studentima

Prilog 10.1. Izvod iz bibliotečke knjige inventara

Prilog 10.2. Izjava o posedovanju računarske laboratorije i broja računara u njoj
\end{abstract}

\title{
Predlog izmene i dopune standarda 10
}

Nedostaje pregled korišćenih knjiga i udžbenika $\quad$ Odbor za visoko školstvo parlamenta i

i u čijoj nadležnosti je kontrola izveštaja.

Ministarstvo prosvete

\begin{tabular}{l} 
Standard 11: Izvori finansiranja visokoškolske ustanove \\
Izvori finansiranja visokoškolske ustanove dovoljni su da obezbede kvalitetno izvođenje nastave \\
najmanje za period zakonom propisanog trajanja studijskog programa. \\
\hline Opis (ne više od $\mathbf{3 0 0}$ reči): \\
\hline Pokazatelji i prilozi za standard 11: \\
Prilog 11.1. Finansijski izveštaji za poslednje tri godine \\
Prilog 11.2. Finansijski plan za tekuću godinu
\end{tabular}


Upravljanje sistemima

\begin{tabular}{|l|l|}
\hline \multicolumn{2}{|l|}{ Predlog izmene i dopune standarda 11 } \\
\hline $\begin{array}{l}\text { Nedostaje u čijoj nadležnosti je kontrola } \\
\text { izveštaja. }\end{array}$ & $\begin{array}{l}\text { Odbor za visoko školstvo parlamenta i } \\
\text { Ministarstvo prosvete }\end{array}$ \\
\hline
\end{tabular}

\begin{tabular}{l} 
Standard 12: Unutrašnji mehanizmi za osiguranje kvaliteta \\
Visokoškolska ustanova donosi i realizuje strategiju obezbeđenja kvaliteta u svome radu. \\
Opis (najviše 100 reči): \\
\hline Pokazatelji i prilozi za standard 12: \\
Tabela 12.1 Lista članova komisije za kvalitet \\
Prilog 12.1. Izveštaj o rezultatima samovrednovanja visokoškolske ustanove \\
Prilog 12.2. Javno publikovan dokument - Politika obezbeđenja kvaliteta- \\
Prilog 12.3. Pravilnik o udžbenicima \\
Prilog 12.4. Izvod iz Statuta ustanove kojim reguliše osnivanje i delokrug rada komisije za kvalitet
\end{tabular}

\begin{tabular}{|l|l|}
\hline \multicolumn{2}{|l|}{ Predlog izmene i dopune standarda 12 } \\
\hline 1. Nedostaje propis o uporednoj analizi kvaliteta & Odbor za visoko školstvo parlamenta i \\
ustanove sa srodnim ustanovama; & Ministarstvo prosvete \\
2. Nedostaju merila za poređenje sa najboljima; & \\
3. Takođe nedostaje standard po kome se na & \\
početku nastave u svakoj godini (semestru) & \\
prijavljuju tačni rezultati upisa studenata na svim & \\
nivoima za tu godinu (semestar). Ovo je bitno & \\
zbog organizacije nastave i pregleda o rezultatima & \\
rada i nastavnika po predmetima ustanove. & \\
\hline
\end{tabular}

\section{Zaključak}

Na primeru standarda koje je propisala Republika Srbija, može se sagledati koje sve uslove treba da ispuni jedna visokoškolska ustanova da bi ušla u proces akreditacije. Standardi su propisima o akreditaciji visokoškolskih ustanova ustanovljeni kao obavezni da bi jedna visokoškolska ustanova mogla funkcionisati na tržištu visokog obrazovanja. Proces akreditacije je proces koji treba konstantno nadograđivati. Ovaj rad predstavlja iskorak na tom polju. Predložena dopuna je širokog opsega pa bi se unapređenje navedenog standarda ticalo i forme i suštine. Kao primer suštinske i kvalitativne nadopune možemo da navedemo predlog dopune standarda br. 12. Ipak, možemo tvrditi da je model unapređenja i kontrole kvaliteta akreditacijom, više formalne prirode, jer se većina navedenih pokazatelja za utvrđene standarde dokazuje upravo papirološki. Pitanje forme i suštine treba da reše zajednički država i sama visokoškolska ustanova koja na tržištu visokog obrazovanja želi da se istakne i bude prepoznatljiva po svom kvalitetu. U svakom slučaju, nakon analize navedenih tabela, može se zaključiti da je proces akreditacije veoma zahtevan u pogledu uslova i standarda koje jedna visokoškolska ustanova treba da ispuni, a $u$ istom trenutku ispunjenje navedenih standarda akreditacije predstavlja kvalitativni minimum za ulazak na tržište obrazovanja. Na jednom kraju štapa će biti obrazovne ustanove koje zadovoljavaju taj minimum, a na drugom one institucije koje ulažu napor ka povećanju kvalitativne prohodnosti svoje ustanove. 


\section{Reference}

[1] Carlos \& A. Calvo (Eds.). (2014). Conocimiento, innovación y emprendedores: Camino al future Spain. Logroño: Universidad de La Rioja. Dobbins,pp. 113.

[2] Huet, I., Rafael, J., Costa, N., Figueiredo, C., \& Oliveira, J.M. (2011). Linking educational research to institutional measures of quality enhancement: a Portuguese project. In: Proceedings from ISQM2011 The 3rd International Conference of Institutional Strategic Quality Management, Romania, Sibiu, Romania, Sibiu, http://ria.ua.pt/handle/10773/8940 - приступљено 20.09.2017. године.

[3] Турањанин, Д., (2018). Bolonjski proces i uticaj na menadžment i kontrolu kvaliteta u visokom obrazovanju, doktorska disertacija. Univerzitet Privredna akademija, Fakultet za ekonomiju i inženjerski menadžment u Novom Sadu, (2018)UKD378:005.96, 005:658.56.

[4] Veiga, A. \& Amaral, A. (2012). The Impacts of Bologna and of the Lisbon Agenda. In Higher Education in Portugal 1974-2009, Springer, Netherlands, pp. 265-284.

[5] Врањеш,М., Гашевић,Д., Дринић,Д., (2014) .Анализа елемената квалитета услуга у високом образовању; Маркетинг, вол. 45, бр. 3, стр. 213-222.

[6] Живаљевић, А., Врцељ, Н.,, Тошовић-Стевановић, А.,: Да ли је квалитет високошколских установа постоји у земљама Западног Балкана?; Индустрија, вол. 43, бр. 1, стр. 91-109, 2015.

[7] Турањанин Д. и Жижовић М., (2007). Удружење дипломираних студената академије (универзитета) и управљање знањем, Факултет за менаџмент Нови Сад, научни скуп: „На путу ка добу знања“, Сремски Карловци.

[8] Турањанин Д., Жижовић М. и Деретић Н.,(2008). Упоредна анализа четири типа студирања код нас, Факултет за менаџмент Нови Сад, научни скуп: „На путу ка добу знања“, Сремски Карловци.

[9] Турањанин, Д., (2003). Принципи квалитета са применом на високо образовање; докторска дисертација; Факултет за менаџмент, Нови Сад, стр. 180-182.

[10] Упутство о акредитацији високошколске установе, донетог на основу Правилника о стандардима и поступку за акредитацију високошколских установа и студијских програма, доступног на https://www.kapk.org/srl\%d1\%81\%d0\%bf\%d0\%ba/ /

https://drive.google.com/file/d/0Bwr8qEMuakSJWXVVYml10GJXcm8/view- приступљено 25.09.2017. године.

[11] Цвијановић, М., Жижовић, М., Лазић,Ј. (2007). Болоњска декларација и менацмент високошколским установама; Индустрија, вол. 35, бр. 1, стр. 113-120. 